\title{
Who was "A. Moore"? The Attribution of Eighteenth-Century Publications with False and Misleading Imprints
}

\author{
Andrew Benjamin Bricker
}

\begin{abstract}
A S SCHOlars of THE PERIOd already well know, most eighteenthcentury British title pages are nothing shy of a bibliographical mess. The most straightforward identifications - who the author is, who printed a given work, and who sold it - are frequently missing. Even worse, when such information is present, it has often been silently falsified. Title pages are simply teeming with misleading and fake attributions: authorial pseudonyms, made-up printers and booksellers, socalled "trade publishers" who had nothing to do with the actual printing or distribution of a given work, even the names of real authors, printers, and publishers who have been added without their approval and despite them having had no hand in the publication.

Presented with this wide range of bibliographical red herrings, how might we begin to sort out who published what during the eighteenth century? The overarching goal of this article is to present a methodology for attributing publications with false and misleading imprints to their unnamed printers. The answer to this problem-how to link publica-
\end{abstract}

Andrew Benjamin Bricker (Department of English, McGill University, Arts Building, Room 265, 853 Sherbrooke St. West, Montreal, QC, $\mathrm{H}_{3} \mathrm{~A} \circ \mathrm{G}_{5}$, Canada) is an Andrew W. Mellon Foundation Postdoctoral Fellow in the Humanities and an Andrew W. Mellon Foundation Fellow of Scholars in Critical Bibliography at the Rare Book School at the University of Virginia. His research focuses on seventeenth- and eighteenth-century satire and libel law. This research has been supported by a joint fellowship from the American Society for Eighteenth-Century Studies and the Bibliographical Society of America.

PBSA 110:2 (2016): 181-214 (C) 2016 Bibliographical Society of America.

All rights reserved. 0006-128X/2016/0110-0002\$10.00 
tions featuring inaccurate imprints back to those who actually printed them-lies in the use of ornament catalogues. Generally speaking, printers reserved their ornaments for their own works in the eighteenthcentury London book trade and only shared them under specific and rare circumstances (though they might be handed down through a dynastic family or sold when a printer died or went out of business). In short, knowing a printer's ornament stock over a period of time would allow us to attribute works featuring false and misleading imprints from the same period to his or her printing house.

Doing so would also allow us to pinpoint, sometimes provisionally but often definitively, one agent in the life cycle of a publication-in this instance, the printing house from which it originated. As a consequence, such an identification, complemented by circumstantial and anecdotal evidence, might also permit us to isolate other figures associated with the same publication, especially those members of the book trade with whom the printer often worked, and perhaps even the anonymous or pseudonymous authors linked with those stationers over the course of their careers.

In this article I focus specifically on the range of plausible-sounding but entirely made-up printers' and booksellers' names regularly found on false imprints throughout the eighteenth century. In particular, I home in on the wholly fictional "A. Moore," the most common of the names found in fraudulent imprints and one that appears on literally hundreds of title pages during the first half of the eighteenth century (see fig. 1). Using extant ornament catalogues, including those published by the Oxford Bibliographical Society, a private ornament catalogue currently housed in Chicago, and my own ad hoc collections, I have managed to attribute dozens of these publications featuring A. Moore imprints to their respective printers.

More than an attempt to work out partially (and all too slowly) the identity of printers for a small group of bibliographically dubious works from the eighteenth century, I present a theory of ornament usage that emerged as I assembled my corpus of Moore imprints. The most intriguing case remains the recurring use of a headpiece and factotum combination in these publications from the 1720 and 1730 s that were in fact printed by the printer-bookseller Thomas Read. The regularity with which these two ornaments were used in tandem, however, also suggests something much more interesting than the mere attribution of 
A

\section{POPP upon POPE;}

Or, A True and Faithful

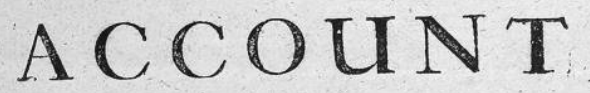

Of a late Horrid and Barbarous

\section{W H I P P I N G}

Committed on the BODY of

$$
S-N-Y \text { P O P E, a Poet: }
$$

As he was innocently walking in $\mathrm{Ham}$ Walks, near the River of Thames, meditating Verfes for the Good of the Publick. Suppofed to have been done by Two evil-difpos'd Perfons, out of Spite and Revenge, for a harmlefs Lampoon which the faid Poet had writ upon them.

Enter'd in the Hall-Book, according to AEt of Parliament.

$L O N D O N$ :

Printed for A. MOORE, near St. PA U L's. MDCCxxvir, (Price One Penny.)

Fig. 1: "A. Moore" Imprint, [Lady Mary Wortley Montagu?], A Popp upon Pope (London, 1728), Printed for A. Moore, near St. Paul's. William Andrews Clark Memorial Library, University of California at Los Angeles. $\mathrm{f} \mathrm{PR}_{3} 633 \cdot \mathrm{M}_{75}$ *. 
a printing house for this group of works. In short, it seems Read (and perhaps others individually) reserved a small collection of ornaments for legally perilous publications. Printers did so, theoretically, because they realized that ornaments might be a way for the legal authorities to do the very thing that I propose here as an investigative bibliographical methodology: to trace illicitly published works with false and misleading imprints back to the printers who actually produced them.

\section{THE PROBLEM WITH EIGHTEENTH-CENTURY TITLE PAGES}

That the title pages of so many eighteenth-century works are a bibliographical disaster will come as little surprise to scholars who have worked intimately with the printed record from this period. Especially problematic are what Michael Treadwell has called "false and misleading imprints." We simply cannot be certain in many instances that "printed by" means the printer, "printed for" means the publisher, and "sold by" means the bookseller. ${ }^{1}$ Those involved in the financing, production and distribution of a given work routinely falsified such information. They often did so to obscure their involvement or to give the misleading impression that a notable author or member of the book trade had participated in the production of the work. Imprints sometimes also contain the names of individuals whom we now call, after D. F. McKenzie, "trade publishers," men and women who were paid a small fee to append their names to the imprint of a given work. ${ }^{2}$ Trade publishers were a new feature of the book trade in the last quarter of the seventeenth century, filling a void created by the period's restrictive licensing laws. ${ }^{3}$ The primary function of a trade publisher, as Treadwell

1. Michael Treadwell, "On False and Misleading Imprints in the London Book Trade, 1660-1750," in Fakes and Frauds: Varieties of Deception in Print E Manuscript, ed. Robin Meyers and Michael Harris (Winchester: St. Paul's Bibliographies, 1989), 29-46. For imprint formulae see W. W. Greg, Some Aspects and Problems of London Publishing between 1550 and 1650 (Oxford: Clarendon Press, 1956), 85; and David Foxon, Pope and the Early Eighteenth-Century Book Trade, rev. and ed. James McLaverty (Oxford: Clarendon Press, 1991), 2.

2. D. F. McKenzie, "The London Book Trade in the Later Seventeenth Century" (Sandars Lectures, 1976), 24-8. MISC 217, Special Collections, Green Library, Stanford University. See also Michael Treadwell, "London Trade Publishers 1675-1750," The Library, 6th ser., 4 (1982): 100, 101.

3. Specifically the Licensing Order of 1643 and the Licensing of the Press Act of 1662 . The authorities never gave up on attempting to regulate the press, even 
argues, was "concealment" in those instances when a controversial pamphlet might be dangerous enough to warrant "the slight added expense of a paying a [trade] publisher to stand between the authorities and the person really responsible." ${ }^{4}$

Trade publishers are one bibliographical problem. But some works were simply too dangerous for even a trade publisher to append his or her name to - works that fell precariously under the seemingly ad hoc umbrella of libel laws, including the defamatory, seditious, obscene, and blasphemous. ${ }^{5}$ Unfortunately for stationers, imprints were legally necessary, according to the Act of Anne (1710), for works to be registered and, according to the Stamp Act (1712), for them to be sold publicly. ${ }^{6}$ To get around these requirements, the overcautious simply made up names for their imprints. John Dunton, for one, used a variety of generic names, such as P. Smart, R. Levis, R. Newcome, and T. Pratt. ${ }^{7}$ The most routinely used name during this period is Moore. Had he actually existed, Moore would have been one of the most prolific booksellers of the early eighteenth century. ${ }^{8}$

during the Act's temporary lapse, relying on royal prerogative, the regulation of hawkers, judicial warrants, and enforcement of the Stationers' Company bylaws (Timothy Crist, "Government Control of the Press After the Expiration of the Printing Act in 1679," Publishing History 5 [1979]: 49-77). In fact, even after the Act's final expiration, Parliament devised more than a dozen bills between 1695 and 1714 in an attempt to reintroduce licensing (John Feather, "The Book Trade in Politics: The Making of the Copyright Act of 1710," Publishing History 8 [1980]: table 1, 19-44). For the Act's expiration in 1695, see Raymond Astbury, "The Renewal of the Licensing Act in 1693 and its Lapse in 1695," The Library, 5th ser., 33 (1978): $296-322$.

4. Treadwell, "London Trade Publishers," 113, 121.

5. The best single article on the relationship between the book trade and the broad canopy of libel laws during this period is Philip Hamburger, "The Development of the Law of Seditious Libel and the Control of the Press," Stanford Law Review 37, no. 3 (1985): 661-765.

6. The Stamp Act (1o Anne c. 19, c. 13) required that "no person whatsoever shall sell, or expose to sale, any [such] pamphlet, without the true respective names, and place or places of abode, of some known person or persons, by or for whom the same was really printed or published, written or printed thereupon."

7. Stephen Parks, John Dunton and the English Book Trade: A Study of his Career with a Checklist of his Publications (New York: Garland, 1976), 200-1.

8. See Evan R. Davis, "Pope's Phantom Moore: Plagiarism and the Pseudonymous Imprint," in Producing the Eighteenth-Century Book: Writers and Publishers in 
Granted, those in the book trade named Moore did in fact exist. Thomas Moore, for instance, was a printer and bookseller in the early eighteenth century, and in 1684 was a defendant in a suit brought by Anthony Trethway in Common Pleas for the recovery of $£_{3} 300 .{ }^{9}$ There was also a printer by the name of John Moore, active between roughly 1720 and 1760 , whose wife was also perhaps named A. Moore. ${ }^{10}$

But as the century progressed it also became clear to readers that the A. Moore imprint was a signal-even something of a stock bibliographical joke in the London book trade. ${ }^{11}$ "The Study of Bookseller is as difficult as the Law; and there are as many Tricks in the one as the other," Bookweight, the bookseller in Henry Fielding's The Author's Farce, laughingly reveals. "Sometimes we give a Foreign Name to our own Labours ... so we have Messieurs Moore near St. Paul's, and Smith near the Royal Exchange."12 So routine was the A. Moore imprint during the first half of the eighteenth century that numerous printers and publishers were actually using it simultaneously (a point I make most clearly below, in section III). As one contemporary observed, "It must be premised that the name of the printer is on these occasions omitted \& A Moor near St. Pauls generally put where the law directs the printers name to be."13

England, 1650-1800, ed. Laura L. Runge and Pat Rogers (Newark, DE: University of Delaware Press, 2009), 193, fig. 3 .

9. CP 35/6, Chas. II, 1683-4, Roll 3020, m. 352, National Archives.

10. An A. Moore in Castle-Street in Dublin was also in business in the later 1720 s and possibly in the 1740s. There were perhaps two Thomas Moores, as suggested by H. R. Plomer, et al., A Dictionary of the Printers and Booksellers who were at Work in England, Scotland and Ireland from 1668 to 1725 (Oxford: The Bibliographical Society, 1922), 209, though evidence for the existence of both is thin.

11. Treadwell, "On False and Misleading Imprints," 41-43.

12. The Author's Farce (1734), in Henry Fielding: Plays, Volume I: 1728-1731, ed. Thomas Lockwood (Oxford: Clarendon Press, 2004), 328. Fielding returned to the joke a few years later; see Contributions to The Champion and Related Writings, ed. W.B. Coley (Oxford: Clarendon Press, 2003), 48, 4 December 1739. Evan R. Davis also advocates for another contemporary allusion to the Moore imprint in the Dunciad ("Pope's Phantom Moore," 202).

13. Cholmondeley (Houghton) MS 74 (34), Cambridge University Library, qtd. in David Foxon, “The Phantom Moore," Bibliography Nerwsletter 1, no. 12 (1973): 6. 
The A. Moore imprint was used for a range of wares. Much of the period's “erotica," for example - works like The Beau's Miscellany (1731), a collection of bawdy poems - features the imprint, a pun ("amour") that perhaps signaled to readers, as Janine Barchas has argued, some form of salacious content. ${ }^{14}$ In most instances, though, the name appears on the title pages of decidedly unerotic works from which those involved perhaps predictably wanted to distance themselves-pieces like Arse Musica; Or, The Lady's Back Report (1722), a satire full of farting puns on the burgeoning taste for Italian opera that gleefully catalogues a range of noted contemporary musicians (especially those skilled at their "wind" instruments), organ makers, and organ-music composers. Or works like Serious and Cleanly Meditations Upon a House of Office (1723), a leveling scatological satire (sometimes attributed to Jonathan Swift), using the familiar device of our digestive tracts, which concludes with an ode to a bog-house in imitation of Milton. ${ }^{15}$ Works of particular satire were also published under the Moore imprint, including The History of the Norfolk Steward Continued (1728), an attack upon Robert Walpole, and The Occasional Writer. No. IV. \& V (1727), a shot at Lord Bolingbroke using the latter's own pseudonym of "The Occasional Writer."

There was almost nothing for which a Moore imprint wouldn't do. The religious controversialist Thomas Woolston, for instance, employed it for A First Free-Gift to the Clergy (1722), the first of four works distributed without charge (three of which used the imprint) attacking the clergy and fortifying his purely figurative, rather than literal, reading of the bible. ${ }^{16}$ For Woolston, the Moore imprint to some extent was an unnecessary layer of subterfuge. He was more than happy to take the

14. Janine Barchas, Introduction, Eighteenth-Century British Erotica, Vol. 1: 17001735 (London: Pickering \& Chatto, 2002), xxiv-xxv. Nonetheless, the term "erotica" only comes into use in the mid-nineteenth century, and many of the works classified as erotica by the editors of the five-volume Eighteenth-Century British Erotica are humorous, satirical, and scatological works with what we might think of as little or no "erotic" import.

15. This document does not appear, however, in H. Teerink, A Bibliography of the Writings of Jonathan Swift, and rev. ed., Arthur H. Scouten, ed. (Philadelphia: University of Pennsylvania Press, 1963).

16. See also A Free-Gift to the Clergy (1722); A Third Free-Gift to the Clergy (1723); and $A$ Fourth Free-Gift to the Clergy (1724). 
fall for his writings and beliefs, something he did repeatedly in the 1720 s for his most blasphemous publications. ${ }^{17}$ But the misleading imprint made clear his position - these were his works - and squared attention on their author, rather than the workaday printer whom Woolston had hired.

The Moore imprint was perhaps revived in the 1770 for the Whisperer, a periodical that was deeply critical of Lord North's administration. Its notoriety has been largely overshadowed by the Junius Letters, a series of pseudonymous satiric screeds directed at a range of public figures and that appeared in Henry Sampson Woodfall's Public Advertiser during the same period. Published a brisk ninety-five times in less than two years, between February 1770 and December 1771, the Whisperer eventually drew the government's ire. A bookseller by the name of Mariner, among others, for instance, was apparently imprisoned ten months for selling it. ${ }^{18}$ The muckraking Richard Francklin also regularly used the Moore imprint for two decades, and most frequently in the 1730s, after he had been successfully prosecuted for seditious libel by Robert Walpole's government for his scathingly satiric periodical the Craftsman. ${ }^{19}$

The reality is that generic but wholly fictional names like A. Moorebut also other imprints, like those used by Dunton, into which printers and booksellers silently substituted wholly fictional names-have wreaked havoc on our bibliographical knowledge. We simply don't know, or have wrongly assumed that we do know, in likely thousands of instances, who published what. But there is a way to begin correcting the record. It lies in the examination of the printers' ornaments that populate a massive percentage of these texts carrying false and misleading

17. William H. Trapnell, "Woolston, Thomas (bap. 1668, d. 1733)," in Oxford Dictionary of National Biography, ed. H. C. G. Matthew and Brian Harrison (Oxford: Oxford University Press, 2004); online ed., January 2008, doi:10.1093/ref :odnb/29963.

18. Charles Henry Timperley, Encyclopedia of Literary and Typographical Anecdote (1842), 162.

19. James J. Caudle, "Richard Francklin: A Controversial Publisher, Bookseller and Printer, 1718-1765," The Cambridge History of the Book in Britain, 1695-1830, ed. Michael F. Suarez, S.J., and Michael L. Turner (Cambridge: Cambridge University Press, 2009), 390-91, table 18.1. 
imprints-small, decorative, and all too easy to miss illustrations that have largely been ignored by literary scholars, if not by book historians.

\section{PRINTERS' ORNAMENTS AND ATTRIBUTION: A METHODOLOGY}

One of the surest ways to identify printers responsible for works that feature dubious, fictitious, or misleading imprints remains their ornaments - woodcut and sometimes engraved metal illustrations, including printers' devices, headpieces, tailpieces, factotums, and pictorial initials, used for decorating letterpress publications - that were individually made and often personalized for their buyers. ${ }^{20}$ Despite sometimes being imitated, ornaments were much more individualized than, say, type. It was rare to have a special fount cut and cast for a single printer. Instead, typefounders used the same matrices again and again, meaning no one fount of type, in almost all instances, belonged to a single printer. ${ }^{21}$ Unlike type, individual ornaments were typically cut for and employed solely by their owners and only changed hands when a "printer died or went out of business." ${ }^{22}$ Charles Ackers, for instance, acquired nearly half of his ornament stock secondhand from a half-dozen printers, the vast majority coming from Samuel Palmer, under whom he had apprenticed. ${ }^{23}$ However, ornaments were also occasionally shared by printers from the same family, even when they ran separate printing houses. Henry Sampson Woodfall, for instance, occasionally used the ornaments of his father, Henry Woodfall, while William Bowyer inherited his father's ornament stock. ${ }^{24}$ Nonetheless, Keith Maslen con-

20. For a discussion of the material used to create printers' ornaments, see contributions by Terry Belanger, David Foxon and Keith Maslen in Bibliography Nerwsletter 1, no. 8 (1973): 1-2; no. 10 (1973): 2-5; and no. 12 (1973): 5-6.

21. Colin Clair, "On the Printing of Certain Reformation Books," The Library, 5 th ser, 18 , no. 4 (1963): 278 .

22. Clair, "On the Printing of Certain Reformation Books," 278.

23. J. C. Cross, Charles Ackers' Ornament Usage (Oxford: Oxford Bibliographical Society, 1990), 8.

24. See Richard A. Goulden, The Ornament Stock of Henry Woodfall, 1719-1747: A Preliminary Inventory (London: Bibliographical Society, 1988), viii; and K. I. D. Maslen, The Bowyer Ornament Stock (Oxford: Oxford Bibliographical Society, 1973), 3 . 
cludes that widespread sharing likely did not occur, especially outside of close relations in the London book trade. ${ }^{25}$

Nonetheless, we need to keep two caveats in mind when examining decorative woodcuts. The first concerns the widespread similarity among ornaments during this period. From the sixteenth century on, ornament makers had developed a standard iconographic repertoire, from classical works and mythology to pastoral landscapes, Roman ruins and urban scenes, all embellished by floral trellises and rococo borders. As a result, a great number of ornaments are quite similar, in some cases seemingly indistinguishable, and only with the most precise attention to detail can an errant cut or original embellishment be identified. A second problem is general wear - a greater issue for woodcut than metal ornaments - where the physical realities of repeated use had the natural tendency to erode and distort woodcut ornaments. Then there were the natural forces that jeopardized the tenures of all woodcutsheat, damp, moisture, and above all the clumsy hands of apprentices and print-house bumblers. These factors make it much more difficult to trace a single well-used and roughly handled ornament over decades of employment.

The most reliable method for identifying the actual printer of a publication with a misleading imprint involves locating an ornament the work contains in the ornament stock used by a known printer both before and after the dubious document's date of publication. For instance, imagine we find are trying to uncover the printer of a pamphlet from 1728 with an A. Moore imprint. Let's imagine this pamphlet features an elaborate woodcut headpiece on its opening page. Let's also imagine we have located the same piece in the ornament stock of a printer named Jonathan Bibliostein. To verify that the work in question emanated from Bibliostein's printing house, we would have to be certain that he in fact owned and used that ornament in 1728. To do so, we would need

25. See Maslen, An Early London Printing House at Work: Studies in the Bowyer Ledgers (New York: Bibliographical Society of America, 1993), 236-37; and Richard Ovenden, "Ornament," The Oxford Companion to the Book, ed. Michael F. Suarez, S. J. and H. R. Woudhuysen (Oxford: Oxford University Press, 2010). See also Mary Pollard, "An Index of Irish Printers' Ornaments of the Eighteenth Century," Long Room I (1970): 41-42; and "Borrowed Twelve Cuts': A Cork Printer Lends and Borrows," Long Room 8 (1973): 19-28. I would like to thank Anne-Marie Diffley and Paul Ferguson, both at Trinity College Library, Dublin, for helping to locate a copy of these articles. 
to find works with a Bibliostein imprint that feature the same headpiece and that both precede and succeed the $1728 \mathrm{~A}$. Moore-imprinted work. Failing to find any pertinent examples might raise doubts about the ornament's provenance: Bibliostein might have owned and used the same headpiece between 1720 and 1727 , for instance, but sold it off or bequeathed it before the work with the Moore imprint was published in 1728. Or he might have inherited or purchased the same headpiece in 1729 from a printer who operated, like so many in the fickle book trade of early eighteenth-century London, for a mere unsuccessful year.

Without confirmed exemplars from both before and after the date of the illicit publication, relying on ornaments might generate false positives. For instance, $H_{-----S S---y}$ to $\operatorname{Sir} C---H-H_{---} W---s:$ Or, The Rural Reflection of a Welch Poet (1746), a satiric poem on Edward Hussey and Sir Charles Hanbury Williams, features an A. Moore imprint and a tailpiece of a boy playing drums (see fig. 2). This same tailpiece was subsequently used by the printer John Hughs in his edition of Edward Moore's Poems, and Fables, and Plays (1756). However, the ten-year gap between appearances along with no known instances of the tailpiece prior to 1746 makes any link between Hughs and The Rural Reflection dubious at best. In the absence of a full ornament catalogue for Hughs, we cannot be certain that he did not simply inherit or buy the same tailpiece in 1755 .

Ornament catalogues are only one method for identifying printers. ${ }^{26}$ Nonetheless, ornaments are the best single way-admittedly somewhat painstaking, but much easier today in its initial phase with the advent of mass digitization projects - to identify the unnamed printers of many eighteenth-century publications. ${ }^{27} \mathrm{I}$ have begun this process by focus-

26. In their biography of Edmund Curll, for instance, Paul Baines and Pat Rogers assemble a formidable collection of Curll publications featuring an A. Moore imprint. Rather than working from ornaments, Baines and Rogers examined bookseller advertisements along with works where the imprints changed from Moore to Curll between editions. See Edmund Curll, Bookseller (Oxford: Oxford University Press, 2007), 75, 124, 130, 196-97, 201, 280, 315.

27. For example, Patrick Spedding managed in a mere few weeks to compile the ornament stock of a single printer using screen captures from ECCO. See Spedding, "Thomas Gardner's Ornament Stock: A Checklist," Script \& Print: Bulletin of the Bibliographical Society of Australia and New Zealand 39, no. 2 (2015): 69-111, esp. 75-77; and "Thomas, Lucy and Henry Lasher Gardner, Opposite St. Clement's Church in the Strand, 1739-1805," Script $छ$ Print: Bulletin of the Bibliographical Society of Australia and New Zealand 39, no. 1 (2015): 21-58. 


\section{Bibliographical Society of America}

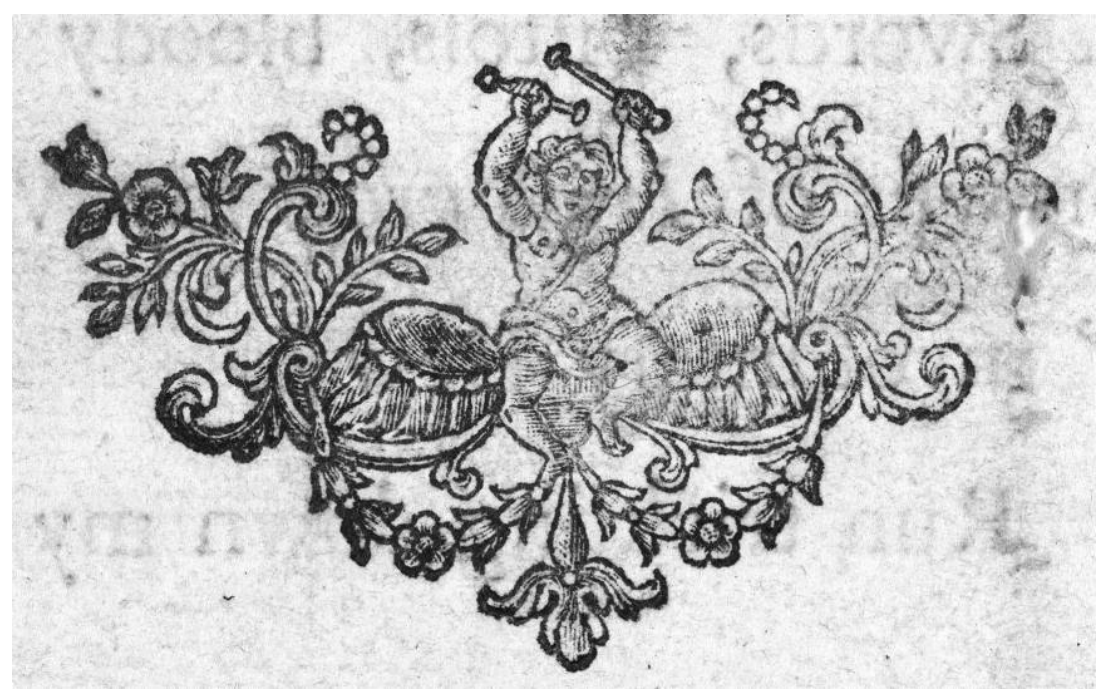

Fig. 2: Tailpiece, $H$------ss----y to Sir $C_{---} H----W---s$ : Or, The Rural Reflection of a Welch Poet (London, 1746), and Printed for A. Moore near St. Pauls, p. 8. Courtesy of The Lewis Walpole Library, Yale University. LWL 53 W67 746r.

ing on A. Moore publications, in large measure because they constitute a massive body of works we know to carry fictitious imprints. But they also, I suspect and tentatively confirm below, reveal in part how the illicit book trade in eighteenth-century London worked in finer detail.

\section{WHO WERE THE “A. MOORE” PRINTERS?}

Focusing on ornaments allows us to identify a range of known printers active during the eighteenth century who were simultaneously publishing works under the name A. Moore. I have identified below a range of such wares by a number of printers operating in the eighteenthcentury London book trade, using three major sources. My first source has been the ornament catalogues assembled and published by the $\mathrm{Ox}^{-}$ ford Bibliographical Society (OBS). These ornament catalogues are of tremendous value, but, at present, only four have been published. ${ }^{28}$

My second major source is a collection of photocopied ornaments from works published roughly between 1710 and 1725 and held in the Bodleian Library. This collection was organized and arranged by John P.

28. J. C. Ross, Charles Ackers' Ornament Usage (1990); R. J. Goulden, The Ornament Stock of Henry Woodfall (1988); J. McLaverty, Pope's Printer, John Wright: A Preliminary Study (1977); and K. I. D. Maslen, The Bowyer Ornament Stock (1973). 
Chalmers, a retired librarian now resident in Chicago, who put together his collection of printers' ornaments between 1970 and 1973 while working on his B. Litt thesis, "Bodleian Copyright Survivors during the first fifteen years of the Copyright Act of Queen Anne, 1710-1726," at Oxford under the direction of David F. Foxon. Each ornament was produced by a library staff member using a photocopier. The printed images came out accurate but slightly reduced. This collection is incomplete, as Chalmers himself observes, but in many instances it provides sometimes small and sometimes extensive ornament catalogues for individual printers. ${ }^{29}$ Nonetheless, Chalmers understands the overall limitations of his collection. As he writes:

In each group there is at least one imprint that provides the name of a printer. There are also numerous imprints that do not. Therefore be warned that all ornaments with brackets around the identification numbers are attributed to the printer named, and must be used with circumspection. In fact, use of this collection should be made with caution because imprints are also known to be false, or to hide the true facts of a partnership. Shared printing also obscures the record. ${ }^{30}$

My third major source has been individual copies of works featuring false and misleading imprints held at the British Library and at rare book libraries across North America, including the Newberry Library, the Morgan Library, the Huntington Library, the Folger Shakespeare Library, the Library of Congress, the New York Public Library, the Rare Book and Manuscript Library at Columbia University, the Albert and Shirley Small Special Collections Library at the University of Virginia, the Williams Andrews Clark Memorial Library at the University of California at Los Angeles, the Beinecke Rare Book and Manuscript Library and the Lewis Walpole Library at Yale University, the Houghton Library at Harvard University, the Kislak Center for Special Collections, Rare Books and Manuscripts at the University

29. Chalmers was able to identify, for instance, James Bettenham as the printer of Alexander Pope's 1728 Dunciad for David L. Vander Meulen's edition of the poem. See Vander Meulen, Introduction, Pope's Dunciad of 1728: A History and Facsimile (Charlottesville: University Press of Virginia, 1991), zonı.

3o. John P. Chalmers, "Some Eighteenth-Century British Printer's Ornaments" (1970-3; rev. 1993), 2. Private Collection, Chicago, Illinois. Examined by the author in April 2015 with the kind permission of Mr. Chalmers. I would also like to thank Will Hansen of the Newberry, who helped to set up my residency at the library and facilitated access to the Chalmers collection, along with Paul F. Gehl and Jill Gage of the Newberry for their assistance. 
of Pennsylvania, Harry Ransom Center at the University of Texas at Austin, Special Collections and University Archives at Stanford University, the Bancroft Library at the University of California at Berkeley, the Thomas Fisher Rare Book Library at the University of Toronto, and Rare Books and Special Collections at McGill University-and the digitized microfilm editions of Eighteenth Century Collections Online $(E C C O){ }^{31}$

I have been cautious in my attributions and have withheld doubtful identifications. In most instances I have tried to use more than one of the above sources, especially when establishing periods of usage for a given ornament. The OBS catalogues include date ranges, while Chalmers's collection sometimes, implicitly, allows one to gain a rough sense of usage dates, but was in many instances only a starting point for locating a specific ornament within a printer's stock, before verifying it against other sources. I often used ECCO, for instance, to locate other printer imprints for additional examples, which I then inspected in person when I was able to gain firsthand access to the same works at rare book libraries.

Following this process, I have been able to identify a number of printers using the A. Moore imprint. Henry Woodfall, for instance, used it repeatedly throughout the 1720 s and 1730 . Remarks, Critical and Political (1726), features a Moore imprint but contains a number of Woodfall's commonly used ornaments. A factotum featuring two cherubs and a basket of fruit from Remarks (see fig. 3 ) had appeared earlier in Edward Hatton's An Intire System of Arithmetic (1721) (see fig. 4), which Woodfall printed. The Remarks' tailpiece, a phoenix on a rococo trellis, later appears in the first volume of Gabrielle Faerno's Fables, in English and French Verse (1741), also printed by Woodfall (see figs. 5 and 6). The recurrence of the Remarks headpiece, an elaborate floral and rococo trellis (see fig. 7), links Woodfall most clearly to the Moore pamphlet. In the buds of two flowers at the center of the headpiece are two initials, $F$ and $H$, the signature of Francis Hoffman, a German engraver and woodcut

31. When permitted, I made high-resolution digital photographs of individual ornaments and catalogued them for reference. I supplemented my research in individual libraries with digitized microfilm editions of works contained in Eighteenth Century Collection Online (ECCO). http://gdc.gale.com/products/eighteenth -century-collections-online/. 


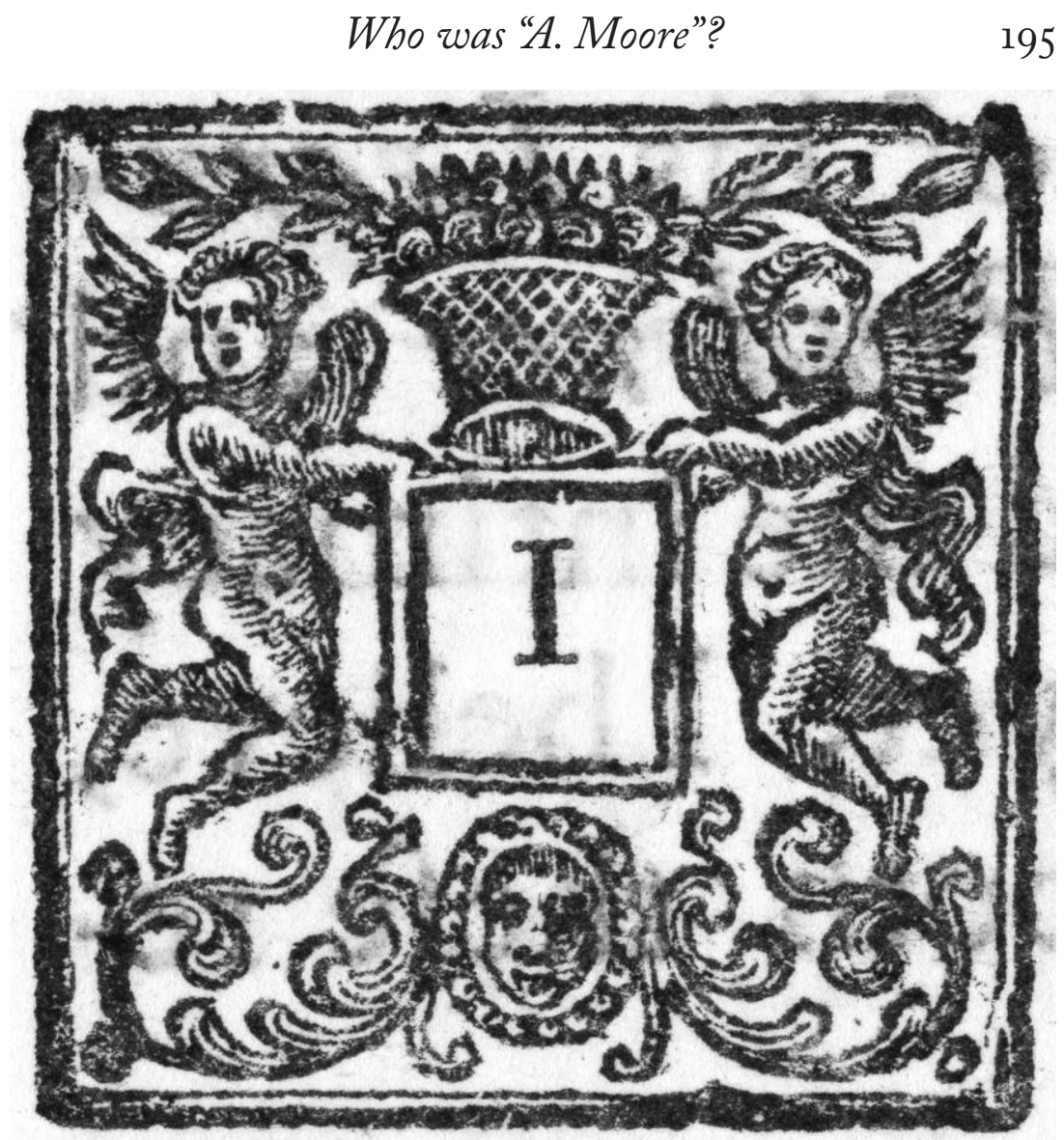

Fig. 3: Factotum, Remarks Critical and Political, Upon a late Poem, Intitled, The Instalment (London, 1726), Printed for A. Moore, near St. Pauls's, p. 3. Courtesy of Lewis Walpole Library, Yale University. LWL 53 Y85 R726.

ornament maker working (and sometimes writing) in London. ${ }^{32}$ The same headpiece later appears in Woodfall's Dr. Warren's Epistle to his Friend (1733) (see fig. 8).

This, though, was not an isolated attempt to fool the authorities over his responsibility for a political tract: Woodfall used the Moore imprint again and again. Take The Speech of Francis Late Lord Bishop of Roches-

32. For more, see "F H (Francis Hoffman) Relief Cuts," Department of Special Collections, University of Florida, 15 May 2000, http://web.uflib.ufl.edu/spec /rarebook/fh/fh.htm. 


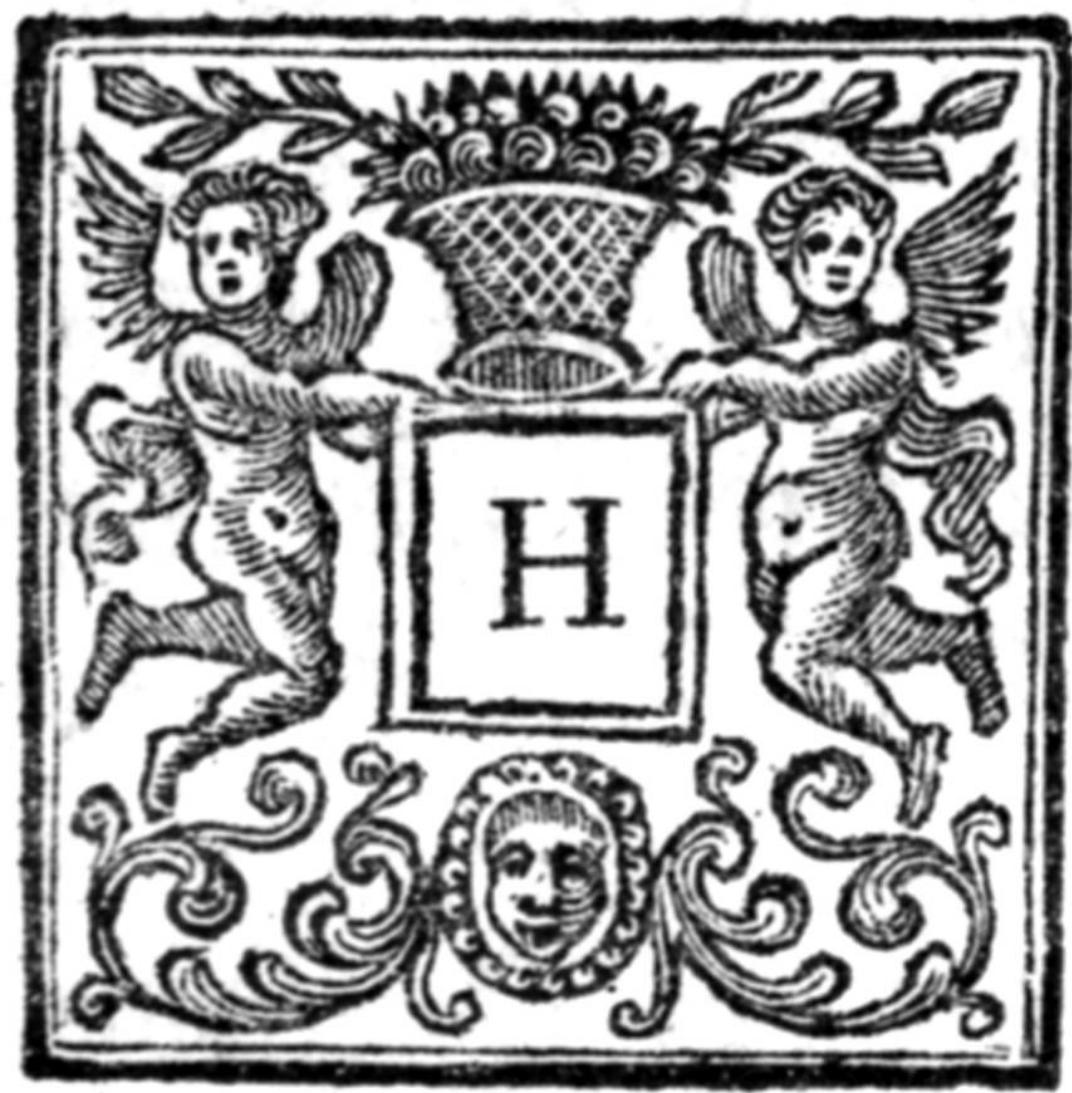

Fig. 4: Factotum, Edward Hatton, An Intire System of Arithmetic (London, 1721), Printed by Henry Woodfall, p. v. Courtesy of Stanford University Libraries, Department of Special Collections. $\mathrm{QA}_{35} \cdot \mathrm{H}_{3} 6$ 1721.

$\operatorname{ter}$ (1723), one of several printed versions of Francis Atterbury's 11 May speech to the House of Lords against a bill of "Pains and Penalties" for his halfhearted involvement in a Jacobite conspiracy in $1722 .{ }^{33}$ The title page of the publication features a tailpiece- a floral trellis enclosing an open book - that Woodfall used repeatedly between 1722 and 1733 in his own imprints.

33. D. W. Hayton, "Atterbury, Francis (1663-1732)," in Oxford Dictionary of National Biography, ed. H. C. G. Matthew and Brian Harrison (Oxford: Oxford University Press, 2004); online ed., January 2008, doi:10.1093/ref:odnb/871. 


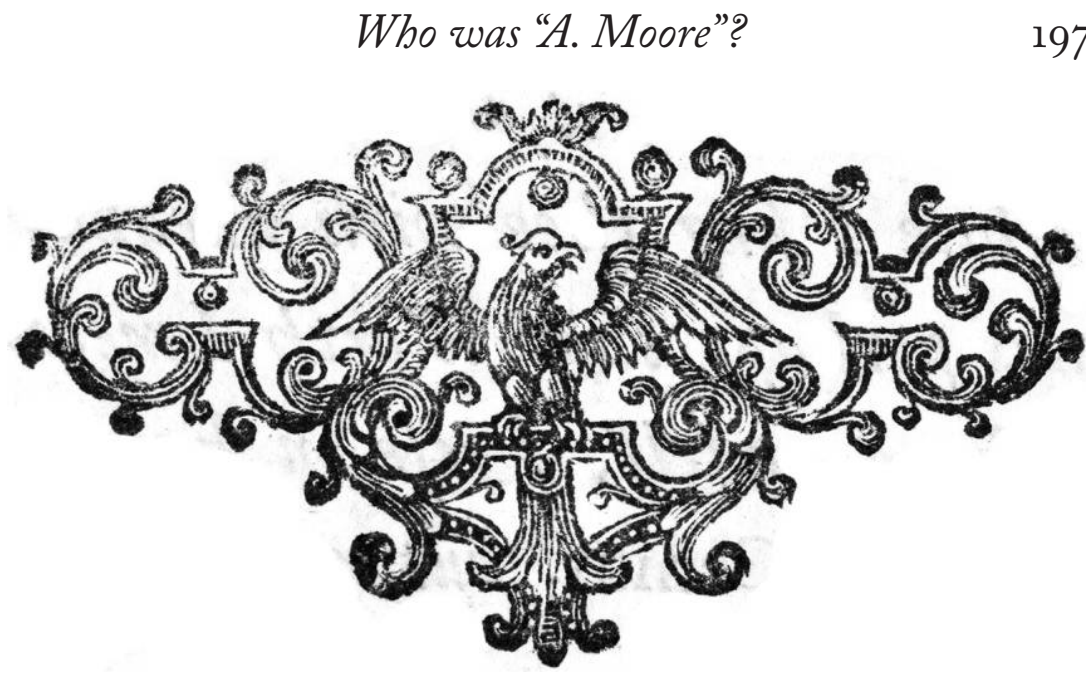

Fig. 5: Tailpiece, Remarks Critical and Political, Upon a late Poem, Intitled, The Instalment (London, 1726), Printed for A. Moore, near St. Paul's, p. 14. Courtesy of The Lewis Walpole Library, Yale University, LWL 53 Y85 R726.

A range of Woodfall ornaments also appears in another Moore imprint, titled Much ado about Nothing: Or, a Plain Refutation (1727), a mocking attack on Mary Toft, the woman who claimed to have given birth to rabbits, written from her own point of view in comically bumpkinish prose. ${ }^{34}$ The pamphlet features a frameless, floral decorative initial $T$, which Woodfall used at least sixteen times between 1724 and 1736; a tailpiece of a floral bouquet that he employed at least twenty times between 1725 and 1734; and two headpieces: one is a fishing scene set among Roman ruins, which Woodfall used sixteen times between 1722 and 1736; the other, signed by Hoffman, features a group of ships, which Woodfall used repeatedly between 1722 and 1727 .

Woodfall wasn't the only London printer who employed the A. Moore imprint during this period. Following is a list of additional identifications I was able to make using Chalmers's collections and the OBS ornament catalogues:

34. A sample: "Undurstandin I hav bin mad a toun tauk of, I thinks it is tim for me to vindikat my self, hoo am as innursent tof what I am exkuz'd with, as the child as is unborn." The rest of the piece features predictably lewd misspellings: "Kuntrivansis," "Prickawshun," and "Affucktation." Much Ado About Notbing: Or, a Plain Refutation (London, 1727), 11-13. 


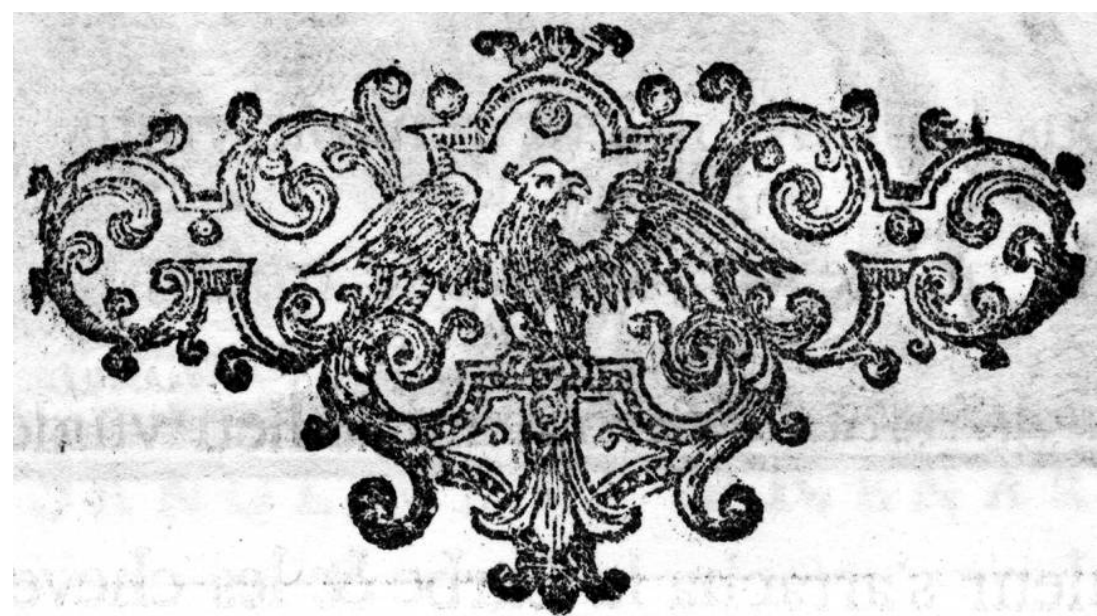

Fig. 6: Tailpiece, Faerno's Fables, in English and French Verse (London, 1741), Printed for Henry Woodfall, 1:131. Courtesy of The Huntington Library, San Marino, California. RB 123420.

Life of the Celebrated Mrs. Elizabeth Wisebourn, nd ed., Printed for A. MOORE, near St. Paul's ([1721?]). Printer: William Wilkins. Ornament: Wilkins T4 (Chalmers), tailpiece of a woman in a wave with a bird. ${ }^{35}$

The Battle of the Bubbles, Printed, and Sold by A. MOORE, near St. Paul's (1720). Printer: William Wilkins. Ornament: Wilkins $T_{1}$ (Chalmers), tailpiece of Phaeton. ${ }^{36}$

A Cursory View of the History of Lilliput, Printed for A. MOORE near St. Paul's Church-Yard (1720). Printer: James Bettenham. Ornaments: Bettenham T21 and $\mathrm{T}_{13}$ (Chalmers), tailpiece of Neptune and tailpiece of Justice. ${ }^{37}$

[Jonathan Swift?], The Benefit of Farting Explain'd, Printed for $A$. Moore, near St. Paul's, and Sold by the Book-Sellers ([1722?]). Printer: Cassandra Meere (widow of Hugh Meere). Ornaments: Meere $\mathrm{H}_{2}$ and $\mathrm{H}_{3}$ (Chalmers), headpiece of man a fishing inside a cartouche, flanked by baskets of flowers, and headpiece of the sun in a cartouche, flanked by cherubs. ${ }^{38}$

Caii Spectrum: Or, Dr. Keyes's Charge Against Dr. M[ead], Printed for A. MOORE, near St. Paul's (1721). Printer: James Bettenham. Ornaments: Bettenham Hio,

35. In Colley Cibber, The Non-Juror, 3rd ed. (1718), 33.

36. In [James Gordon], Popery against Christianity (1719), xxvi.

37. In Geoffrey Keating, General History of Ireland (1723), (b) $1^{\mathrm{r}}$; and Charles Wheatley, Rational Illustration of the Book of Common Prayer of the Church of England, 4th ed. (1722), 529 .

38. In Richard Bradley, Survey of Ancient Husbandry (1725), $3^{\mathrm{r}}$ and $\mathrm{a2}^{\mathrm{r}}$, respectively. 


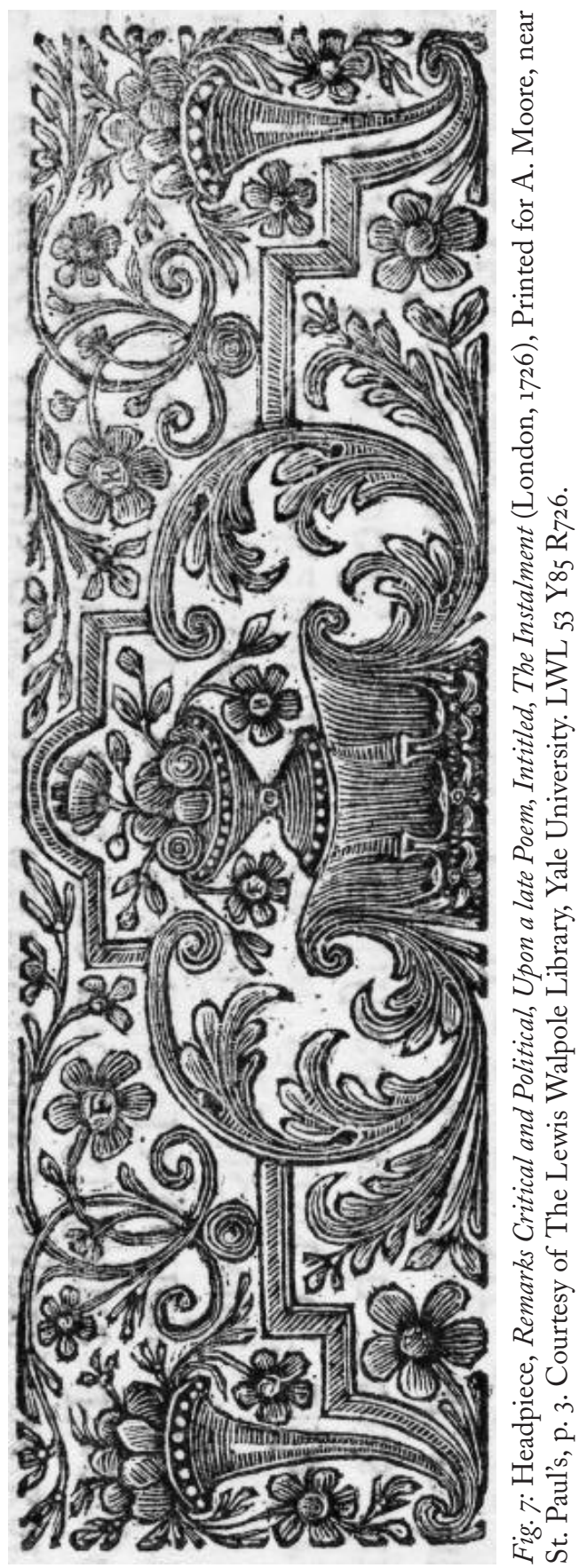



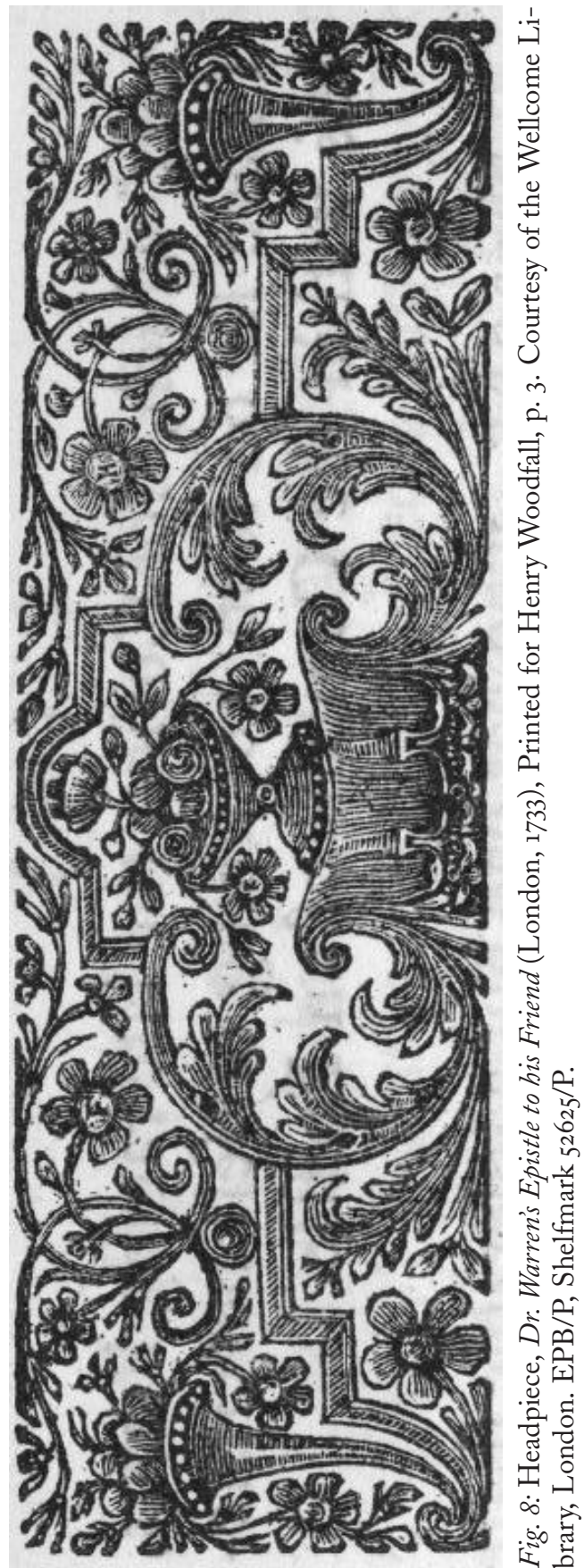
*T56, and $\mathrm{T}_{11}$ (Chalmers), headpiece of an angel, tailpiece of two parallel angels holding horns, and tailpiece of two parallel floral baskets, with birds above both. ${ }^{39}$

Advice to the Ladies of Great Britain, Printed for A. Moore, near St. Paul's (1730). Printer: Henry Woodfall. Ornament: T239 (Goulden), tailpiece of a floral basket with two birds and featuring the Francis Hoffman signature "FH."

A Compleat Collection Of all the Verses, Essays, Letters and Advertisements, which Have been occasioned by the Publication of Three Volumes of the Miscellanies, by Pope and Company, Printed for A. Moore, near St. Paul's (1728). Printer: Henry Woodfall. Ornaments: $\mathrm{H}_{40}$ and $\mathrm{FI}_{373} \mathrm{I}$ (Goulden), headpiece of a bird in a cartouche at center flanked by two floral baskets and two birds, and a decorative framed initial, the letter "I", flanked by floral baskets and featuring the Francis Hoffman signature "FH". ${ }^{41}$

Remarks on A late Book, intitled, An Essay on the Publick Debts of this Kingdom, Printed for A. Moore, near St. Paul's (1727). Printer: Henry Woodfall. Ornament: $\mathrm{H}_{45}$ (Goulden), headpiece of three floral baskets. ${ }^{42}$

That this method of identification and attribution works effectively should be clear from the foregoing list. Moreover, given the contents of these works, Treadwell is certainly right that fictitious imprints of this sort were appended to publications to create distance between the work itself and those responsible. The most interesting aspect of this collection of works is that it confirms what Fielding's bookseller jokes about in The Author's Farce: multiple printers were using the A. Moore imprint simultaneously, and knew, apparently, that that they were not alone.

By the same token, given the fact that a publicly performed play like The Author's Farce could make this kind of inside-baseball joke at all, we can also assume that such false imprints, by the late 1720s, were known to some theatregoers and presumably book buyers. Misleading imprints in effect constituted one ambiguous element of what Eleanor Shevlin

39. In Anthony Sparrow, A Rationale, Or Practical Exposition of the Book of Common Prayer (1722), ${ }^{\pi} \mathrm{A} 2^{\mathrm{r}}$ and $\mathrm{g} 8^{\mathrm{r}}$; and Charles Wheatley, Rational Illustration of the Book of Common Prayer of the Church of England, 4 th ed. (1722), 80.

40. In William Broome, Poems on Several Occasions (1727), 81.

41. In Thomas Bradbury, Twenty-Eight Sermons Concerning Offences (1723), xix; and George Waldron, The Compleat Works (1731), 154.

42. In Mary Davys, The Works of Mrs. Davys, 2 vols. (1725), 2:9. 
has called the title page's "contractual functions." ${ }^{43}$ For this reason, such imprints might have been legally deceptive, but they were also, for stationers and consumers alike, part of the title page's commercial code. The Moore imprint in particular was a dubious signal for London readers - a bibliographical cipher for the knowing, one associated with the sorts of publications that were always worth taking a closer look at.

My experience of working on the ornaments contained in these Moore publications also led me to another theory, one only partially borne out by the evidence, but one that suggests, nonetheless, that printers exercised an even higher level of caution and circumspection than we have always perhaps assumed.

\section{RESERVING ORNAMENTS FOR FICTITIOUS IMPRINTS: THE CASE OF THOMAS READ}

That theory goes something like this: at least some printers realized that the authorities could use ornaments to track down the printing house responsible for a legally perilous work-much in the same way that I was able to attribute a range of works with Moore imprints to the printers responsible - and, as a precaution, they reserved a set of ornaments for works carrying false or misleading imprints.

This theory emerged as I tracked a series of Moore imprints that featured the same sets of ornaments - and especially one headpieceagain and again. That headpiece, it turns out, belonged to the printerbookseller Thomas Read (fl. 1725-51). That he was behind so many works with Moore imprints is perhaps unsurprising. For the most part, Read published, as scholars of bibliography and book history put it, a lot of garbage: potboiler novels, anti-Quaker satires, tell-all multi-volume transcripts of trials for treason, rape, murder, heresy and bigamy; a reprint of John Reynolds's highhanded The Triumphs of God's Revenge (1740); and gastronomically themed satires, including new editions of Warm Beer, A Treatise (1741) and Henry Carey's A Learned Dissertation on Dumpling; Its Dignity, Antiquity, and Excellence. With a Word upon Pudding (1744). His bread and butter for a long stretch was Joe Miller's Jest-Book, a widely reprinted collection of jokes filled with wooden punch lines

43. Eleanor Shevlin, “To Reconcile Book and Title, and Make 'em Kin to One Another': The Evolution of the Title's Contractual Functions," Book History 2 (1999): 42-77. 
on a range of downtrodden figures, including old women, rape victims, dwarves, and cripples. ${ }^{44}$

Judging by the printed record, around 1737 Read's private life took a turn. Between then and 1740, a range of faintly lewd and largely misogynistic works appeared under his own imprint, including a reprint of Ned Ward's Little Merlin's Cave. As it was Lately Discover'd, by a Gentleman's Gardener, in Maidenhead-Thicket (1737) and Celibacy: Or, Good Advice to Young Fellows to Keep Single. In which are Painted, in Very Lively Colours, the Pictures of Many Terrible Wives (1739). Like so many down-market printers from the period, Read found himself, perhaps unsurprisingly, on the fringes of the law. ${ }^{45}$

The most interesting set of Read publications, however, appears earlier. At least seven works with the Moore imprint produced between 1728 and 1730 share the same headpiece representing three allegorical figures from left to right: a woman with a hive and bees, a figure wearing a crown holding a scepter whose head is surrounded by stars, and a woman with an eagle and anchor (see fig. 9):

[Charles Beckingham?], Sarah, the Quaker, to Lothario (1728) (published 19 December 1728: Monthly Chronicle)

Sarah, the Quaker, to Lothario, and ed. (published 1729)

[Hildebrand Jacob], The Silent Flute (1730) (published 27 January 1729: Monthly Chronicle)

[Hildebrand Jacob?], The Church Too Hard for the State (1729) (published 3 February 1729: Monthly Chronicle)

[John Gay?], The Banish'd Beauty (1729) (published 4 March 1729: Daily Journal)

The New Dozen at Westminster; Or, Caleb's Good Men, and True (1729) (published 24 December 1729: Monthly Chronicle)

An Epistle from Matt of the Mint (1730) (published I March 1730: Craftsman)

With the exception of the second edition of Sarah, the Quaker, these titles also share the same factotum, which contains two cherubs flanking the letter space and a lion's head at its base (see fig. 10). Neither this headpiece

44. For a discussion of such works, see Simon Dickie, "Jestbooks and the Indifference to Reform," in Crueltv and Laughter: Forgotten Comic Literature and the Unsentimental Eighteenth Century (Chicago: University of Chicago Press, 2011), ch. 1. 45. See, for instance, SP $36 / 70 / 67$ and SP $36 / 65$, the National Archives, for his involvement in the printing of $A$ Compleat Set of Charts of the Coasts of Merryland (1745), an illustrated work of erotic topography that has not survived. 


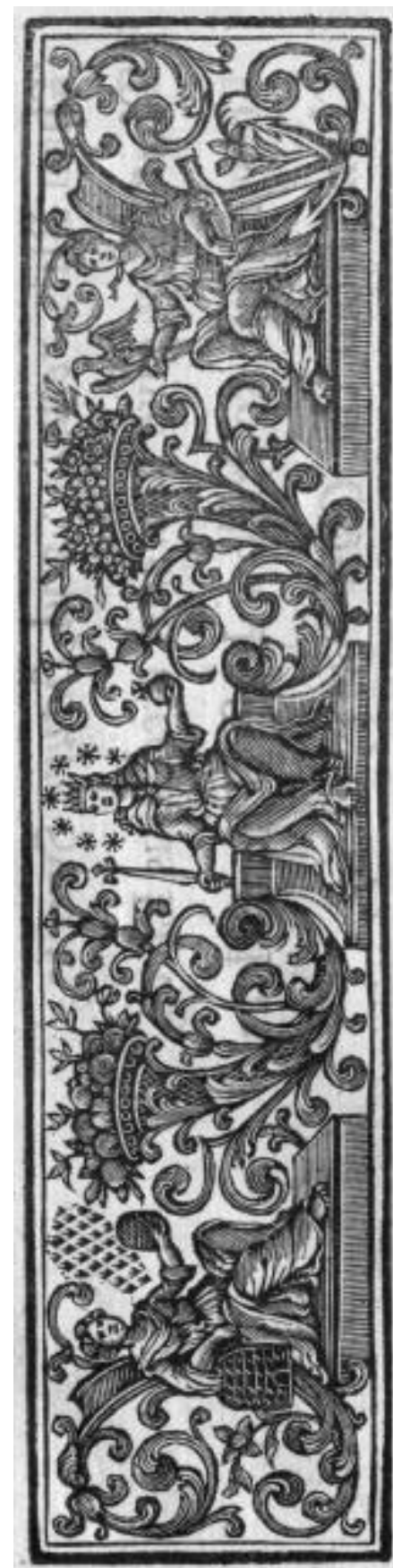

త్త

$\approx+$

है

崩

娄

đ․

ญ.

$\sum^{\circ}$

$\dot{<}$

苞包

प्रुण

记

a.

ก.

हี

$\exists$

ฟั้

$\approx 0$

$\leqslant$

के

马्य

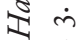

$\therefore$

$\vdots$.

छ

हैंड

ก. 굴

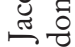

등

폰,

है

寻离

is

.

웜

工我要

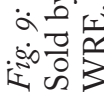




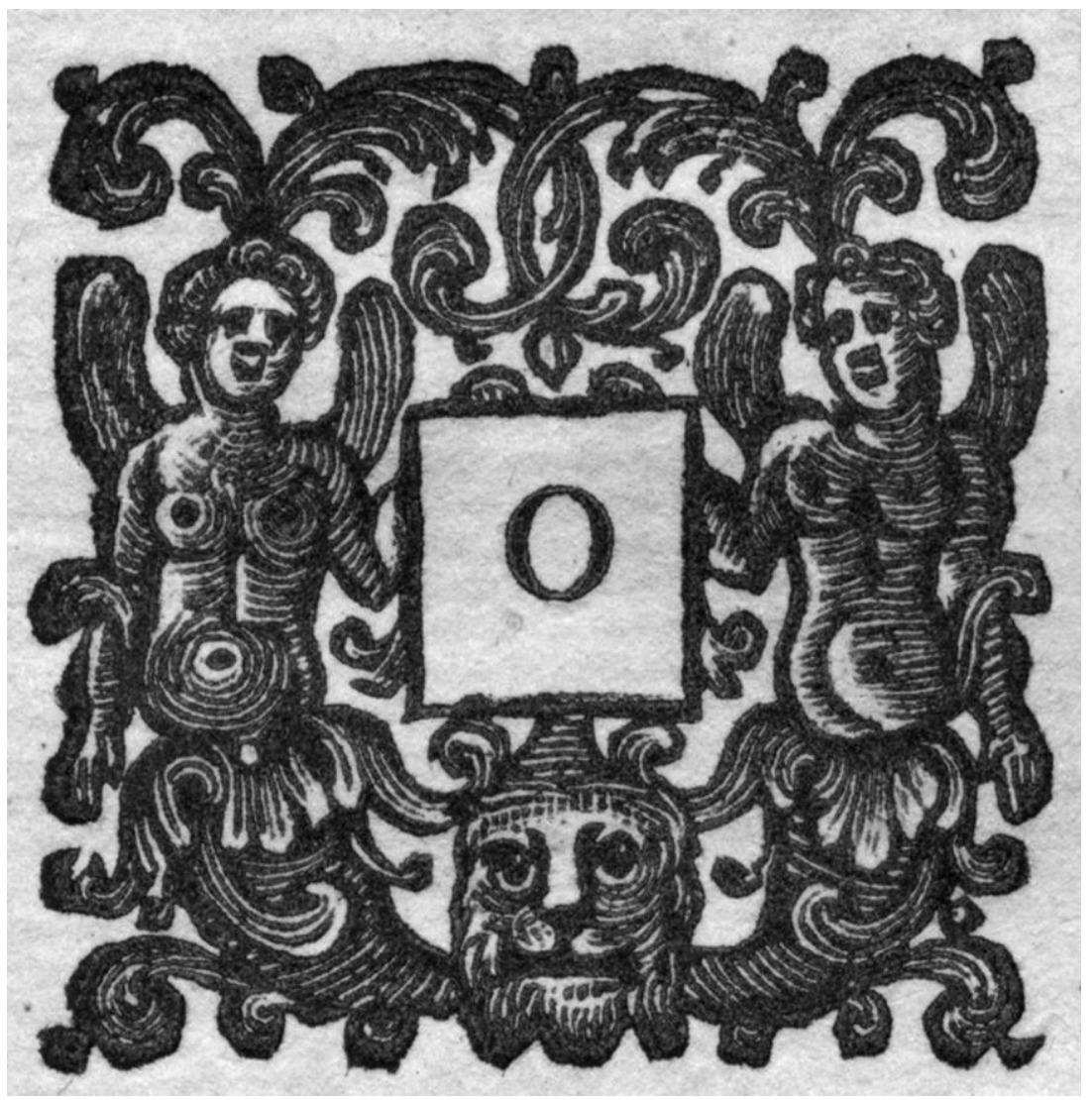

Fig. 10: Factotum, [Hildebrand Jacob?], The Church Too Hard for the State (London, 1729), Printed for A. Moore near St. Paul's, and Sold by the Booksellers of London and Westminster, p. 3. Henry Ransom Center, University of Texas at Austin. Wk A100 +729c WRE.

nor this factotum is recorded in the OBS catalogues or Chalmers's personal collection. However, of these items, The Banish'd Beauty - a verse satire on the Duchess of Queensbury, sometimes attributed to John Gay-was reprinted multiple times. The first printing of the poem appears in a two-sheet folio format in 1729 as The Banish'd Beauty: Or, a Fair Face in Disgrace, A Poem, and its title page bears the Moore imprint. Subsequent impressions of the first edition appeared three more times in short order, each with Read rather than Moore listed in the imprint: the first with only the imprint replaced, the next two misleadingly advertised as the second and third editions on the title page. Read also 
printed an octavo edition in 1729. (A pirated broadside edition printed by Richard Dickerson in Dublin also appeared the same year).

Let's pause here to go over a few theories that might explain why Read issued four separate impressions of the same edition using different versions of the main title page for each. The first, and least likely, is that the first issue was not in fact printed by him. Instead, he bought the entire remaining stock from the original printer, canceled the title pages, and then sold them himself after closely imitating the original title page. This theory assumes that the original printer produced a large number of copies in the initial run but for some reason decided to sell those that remained after the first issue to Read, despite the fact that the title was selling well. In addition, my careful examination of multiple copies revealed no physical evidence that the title leaf of the outer sheet had been canceled. A second theory seems equally unlikely. In it, Read first prints the poem under the Moore imprint, but after the poem is safe from prosecution or litigation, he decides to add his name to the now bestselling work. He cancels the Moore title pages on the remaining copies and prints new ones with his name. These new title pages either: (i) carefully replicate the original title page (which is unlikely and unnecessary: why try tediously to duplicate the mise en page of the illicit impression?); or (ii) had been printed at the same time as the Moore title pages and were secretly stored, because Read anticipated that he would be able to sell the publication under his own name after a period of safety. Again, my examination of extant copies shows no evidence that either the title leaf or the outer sheet were canceled.

The most likely explanation is that Read first printed the poem with the Moore imprint. Then, after the poem was safe from prosecution or litigation, he decided his name could appear on the title page. During the sale of the initial limited print run, he sensed the title's rising popularity and produced another impression with his own name in the imprint. He then later attempted to revive sales by printing a "second" and "third" edition, although the only changes he made were minor alterations to the title page.

If this last theory is correct, then this would also mean that, no matter when he printed the outer sheets for each of the impressions of The Banish'd Beauty, Read's printing house also therefore produced all of the seven Moore publications discussed above and owned the headpiece used in all of them (and the factotum used in six). Unless the first Readimprinted edition is a pirated work with a misleading imprint by the 
same printer who originally printed the Moore version (which is, again, highly unlikely), then we can confidently assume that Read printed all four folio impressions of The Banish'd Beauty and that he therefore owned in 1729 the headpiece and factotum used in numerous Moore publications between 1728 and 1730. As a result, we can also confidently assume that, at the very least, his printing house produced multiple Moore imprints during this period.

That Read was printing illicit works for extra money makes sense: he had only established himself as a printer in the mid-1720s. ${ }^{46}$ We know how competitive the London print trade was and how routinely printers and booksellers folded. Printing faintly scandalous material with a readymade audience was a good way to turn a quick profit for newer stationers without either the economic or cultural capital to land major, popular, or famous authors.

What strikes me as most interesting about these Moore publications is the consistency with which Read used the same combination of ornaments: the headpiece with the three allegorical figures and the factotum featuring the angels and lion. This consistency might have been a simple accident. All of the Moore imprints and all of The Banish'd Beauty impressions featuring these two ornaments appeared in the same two-sheet folio format, and perhaps it made sense to use the same folio-sized headpiece every time, presuming: (a) that Read did not own other headpieces of a similar size (which was not the case; see below); or (b) that Read's compositor typeset these works in succession, and simply recycled the ornaments from publication to publication (which, again, seems unlikely, given the periods of time between each publication and the likely small print runs for such works, probably in the range, at most, of a mere few hundred copies each).

All of this raises the possibility that something much more strategic and cautious was going on. Let's try out another theory. Perhaps Read realized that his ornaments were the only distinctive feature of a potentially illicit publication that would link the work itself with his printing

46. H. R. Plomer, et al., A Dictionary of the Printers and Booksellers who were at Work in England, Scotland and Ireland from 1726 to 1775 (Oxford: The Bibliographical Society, 1968), identifies Read at work by 1726 . However, the imprint of an abridged edition of Moll Flanders from 1723 reads "London: printed and sold by T. Read, behind the Sun Tavern in Fleetstreet," where Read was resident until the mid- to late 1720s, when he relocated to "Dogwell-Court, White-Fryers, Fleet-Street." 
house. That is, just as I have been able to deduce who printed which Moore publication by locating ornaments in self-attributed works published during the same period of time, Read realized that the authorities could potentially identify his surreptitious printing by examining other works bearing his imprint. Such bibliographical paranoia might have been merited. Just days before the first issue of The Banish'd Beauty appeared on 4 March 1729, the Secretary of State for the Northern Department, Charles Townshend, wrote to the Messenger of the Press, Samuel Gray, calling for his agents to buy up a copy of every pamphlet and newspaper published to create a solid evidentiary record for potential later prosecutions. ${ }^{47}$

If this theory is correct - that this wary printer of so many muckraking satires suspected that the authorities, with a little bibliographical sleuthing, could trace misleading imprints back to the printing houses that produced them - then Read perhaps also had a dedicated set of ornaments he used only for illicit publications featuring false or misleading imprints. Setting aside a group of ornaments to produce an at least semi-elegant-looking folio or quarto edition by the standards of earlier eighteenth-century printing would have been easy and fairly inexpensive, requiring only a headpiece and factotum for the first page of the poem or pamphlet proper, a tailpiece for the final page, and an optional ornament for the title page.

In addition, we know Read owned a decent stock of ornaments, which suggests he did not need to use the same headpiece again and again for his Moore imprints simply because he lacked alternative ornaments. Focusing solely on Read's stock of headpieces - which I assembled using ECCO and a wide range of works with his own imprint held in rare book libraries - we know he owned, for instance, at least two headpieces that he used in duodecimos between 1723 and 1728 and during 1730, respectively; fourteen headpieces found in octavos, at least six of which he owned and used between 1727 and 1730; and two headpieces for quartos (though he only used these between 1737 and 1740). Most importantly - because The Banish'd Beauty was imposed in folioRead also owned at least eight headpieces he used for folio printing over the course of his career, meaning the repeated use of the headpiece

47. See Townshend to Gray (1 March 1728/9), KB 33/5/6, National Archives. 
featuring the three allegorical figures was not necessary. Between 1728 and 1730, when these Moore imprints appeared, Read or his compositor could have chosen from at least three folio headpieces: the three allegorical figures; a phoenix below a sun at center flanked by rococo trellises; or a dove in a cartouche at center flanked by two angels blowing clarions. All of this is to say that Read or his compositor used the first of these three headpieces on his Moore imprints not for a lack of choice.

That Read set aside at least two ornaments solely for his pseudonymous imprints (see figs. 9 and 10) is possible, perhaps even plausible, given the frequency with which the same headpiece-factotum combination appears over several years, and at least across twenty-seven months between 1728 and 1730. Again, this headpiece-factotum combination appears only in Read's Moore imprints. The lone exception-the three reimpressions of The Banish'd Beauty that feature T. Read imprints and were likely produced shortly or immediately after the initial Moore impression-is intriguing. For it seems these impressions of the poem are the only works with Read's imprint that ever feature either of these ornaments.

Here is perhaps the most important point: that the headpiecefactotum combination appears in these editions at all might be his compositor's mistake. The compositor reimposed the outer forme of the first gathering and emended only the title-page imprint while preparing it for the press; the remaining formes were reimposed but with no changes whatsoever. Thus the inner forme of the first gathering and both formes for the second gathering on the Moore impression were also used in the subsequent impressions featuring Read's imprint. The result was that Read's compositor had created an ornamental and thus accidental bridge between the two imprints. For the first and only time ever, a Read imprint contained these two ornaments - two ornaments Read or his compositor had conscientiously, it seems, reserved for publications bearing false imprints.

All of this suggests an unexpected level of caution and strategy on the part of Read: that he reserved a set of ornaments for his illicit publications, presumably because he knew ornaments could be used to source the printing house of an illicit publication. If Read had purposely set aside this pair of ornaments for his publications bearing false or misleading imprints, and because that same combination, either in tandem 
or individually, was never used again either before or after in his own imprints, then the appearance of the combination in these editions of The Banish'd Beauty is an anomaly, and perhaps, as I am suggesting, a mistake. In short, Read reserved this combination for illicit publications, but his compositor had neglected to switch out the ornaments when he changed The Banish'd Beauty from a Moore to a Read publication.

We might then ask a further question: Was Read alone-or did other printers exercise a similar level of caution? My theory that printers reserved a set of ornaments for potentially illicit works, I fully admit, is largely circumstantial. And yet other evidence also suggests that we can draw similarly tentative conclusions about additional printers. For a wide range of Moore imprints I was simply unable to find a single match for any ornament present in any of the ornament catalogues and resources I used. Admittedly, many works from the first half of the eighteenth century fell through my net of publications and ornament stocks - many printers, simply put, likely never attached their names even once to the imprints of the thousands of works they collectively printed. And yet it appears other printers, like Read, reserved ornaments for illicit publications. Repeatedly, for instance, I came across Moore imprints that used the same ornament: either an elaborate factotum of a large ship with three masts (fig. 11) 48 $^{4}$ a handsome factotum featuring a row of buildings at its base with the letter space flanked by floral tendrils (fig. 12) ${ }^{49}$; or an intricate headpiece of a pastoral scene of a painter looking at a Roman ruin, with another man and a dog in the foreground (fig. 13)..$^{50}$

Perhaps then Read was not alone in reserving a set of ornaments for illicit publications. Again, the evidence is circumstantial and conjectural-and yet it is also, if the case of Thomas Read is to be trusted, highly suggestive and perhaps illustrative of a more widespread trend in the close-knit and sometimes conspiratorial world of early eighteenthcentury printing and bookselling.

48. See, for instance, The Circumvention, Or, The Amorous successful Politician; $A$ Tale (1727), 3 (April 1727: Monthly Catalogue); and The Woman's Advocatel:] Or The Baudy Batchelor out in his Calculation (1729), 3 .

49. See, for instance, Mr. Aislabie's Two Speeches Considered (1721), 3; and The Wonder of all the Wonders, That ever the World wonder'd at (1722), 3.

50. See, for instance, Button, and Button-Hole: With a Character of the Drabs (1723), 3; Greenwich-Park: Humbly Inscribed to his Grace the Duke of Montagu (1728), $\mathrm{ar}^{\mathrm{r}}$; and [Richard Savage], An Author To be Lett (1729), iii. 


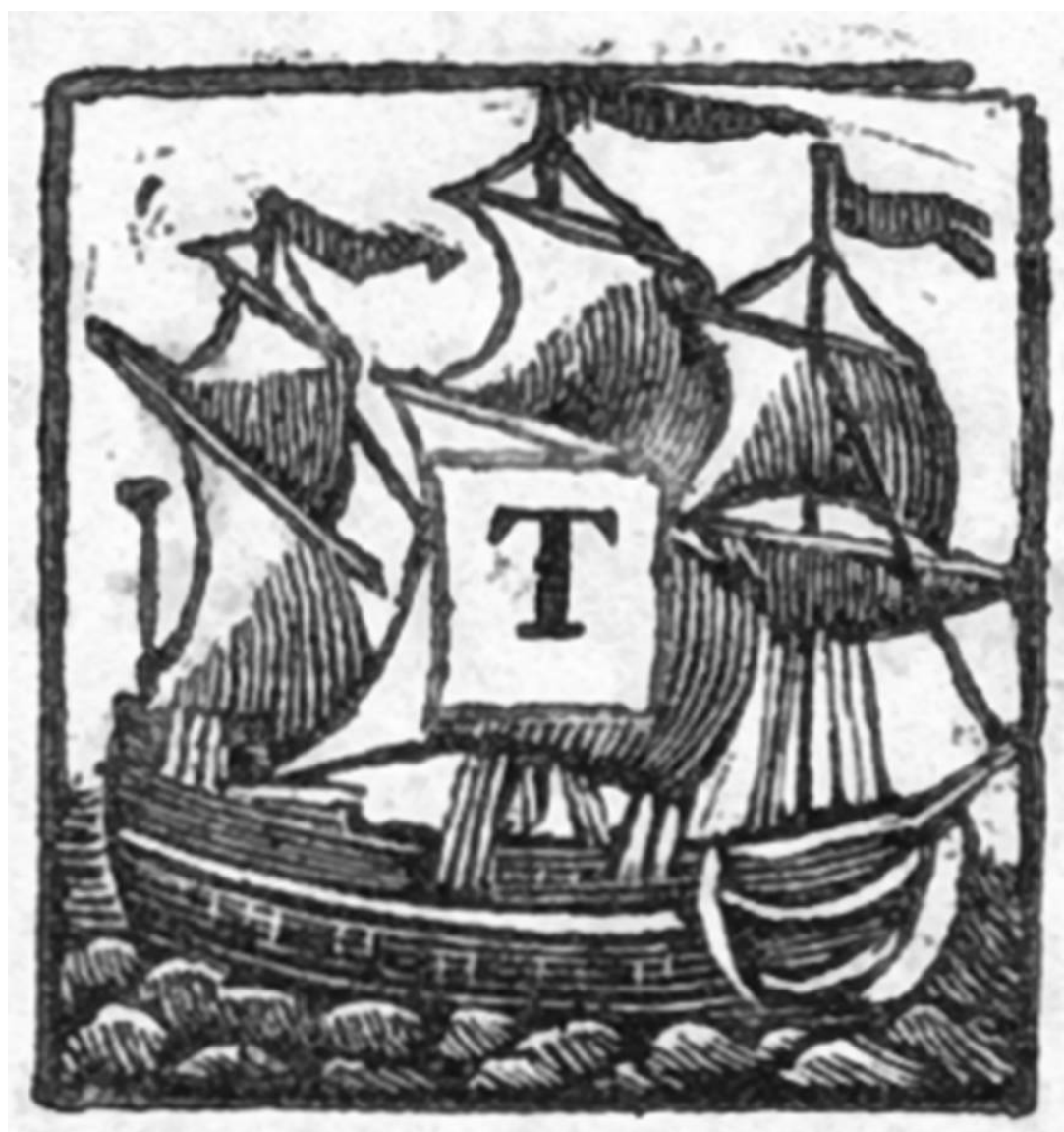

Fig. 11: Factotum, The Circumvention, Or, The Amorous successful Politician; A Tale (London, [1727]), Printed for A. Moore, near St. Paul's, And Sold, by the Booksellers of London and Westminster, 3. Courtesy of the Rare Book Division, Department of Rare Books and Special Collections, Princeton University Library. (Ex) 3600.001 .255 .

\section{A. MOORE, PRINTERS' ORNAMENTS, AND THE BIBLIOGRAPHICAL RECORD}

My theory that printers reserved a special set of ornaments for illicit works is merely a theory, and one only partially borne out by the printed record. That this might be the case is an interesting finding, but it is nothing more than a fortuitous consequence of applying this method of attributing printers to eighteenth-century works featuring false and 


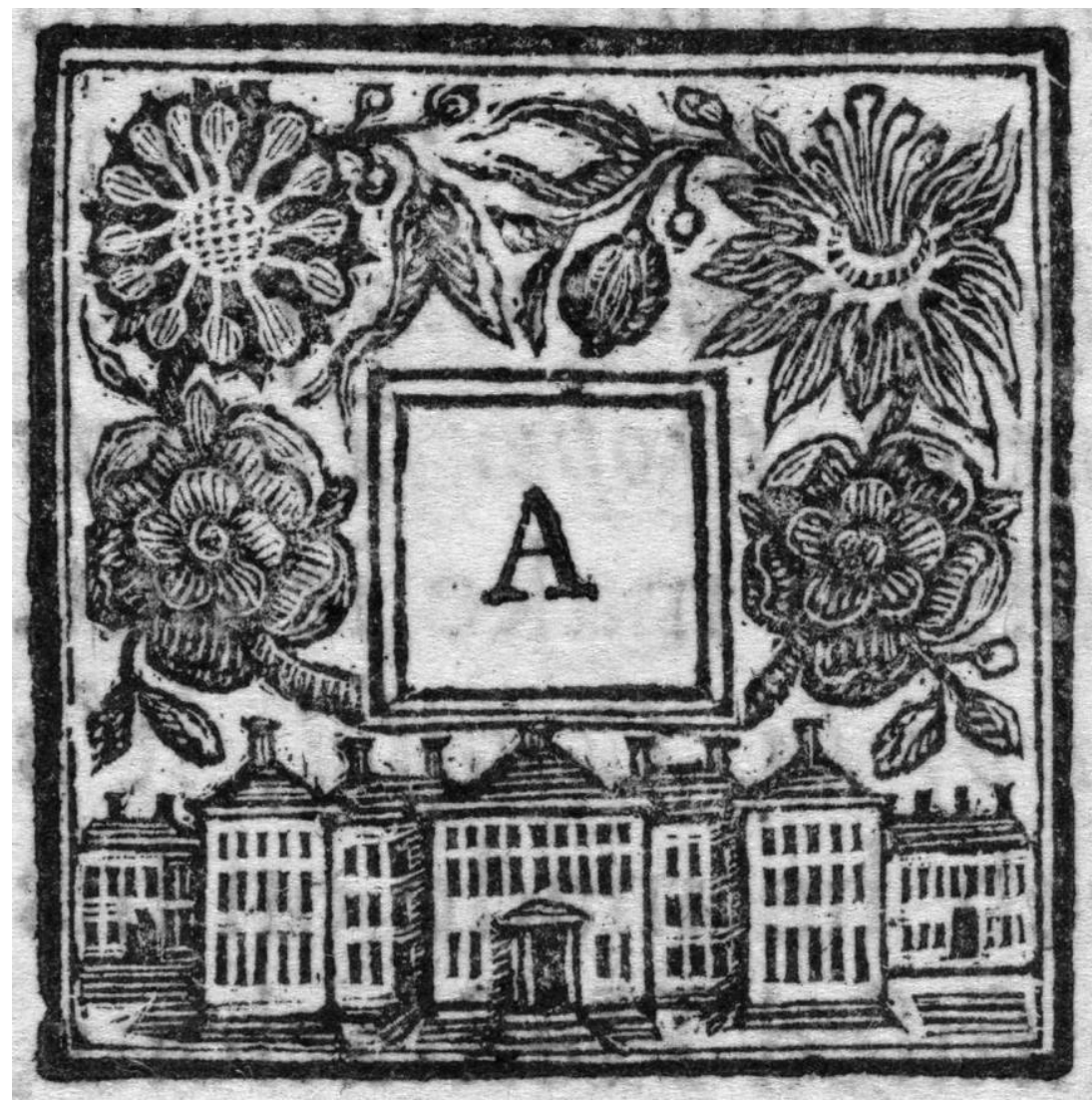

Fig. 12: Factotum, Mr. Aislabie's Two Speeches Considered (London, 1721), Printed for A. Moore, near St. Paul's, and Sold by the Booksellers of London and Westminster, p. 3. Courtesy of the Division of Rare and Manuscript Collections, Cornell University Library. DA483.A5 441721.

misleading imprints. Establishing definitively that printers routinely reserved a set of ornaments for illicit works would take an enormous bibliographical effort-in effect, the assemblage of a master catalogue or database of every ornament used between roughly 1700 and 1750 .

That alone would be a tremendous discovery. But the larger, more important, and more general payoff of this article is a replicable method for attributing printers to eighteenth-century works featuring dubious imprints. The bibliographical mess that is eighteenth-century title pages has caused book historians, bibliographers, and scholars working 


\section{Who was "A. Moore"?}

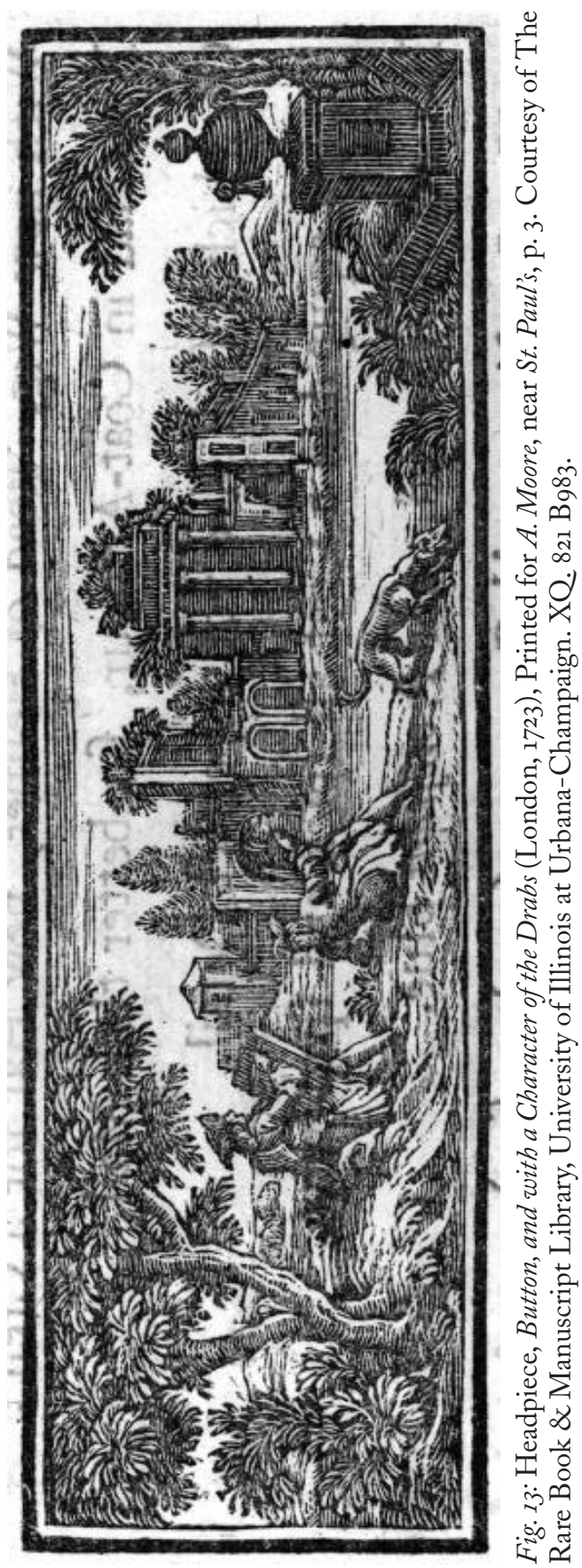

This content downloaded from 142.103.160.110 on June 19, 2018 00:34:40 AM 
closely with the historical record untold numbers of sleepless nights. But even worse has been the overall uncertainty with which students of the eighteenth century have had to approach - or should have approachedthe first-hand study of books themselves from this period. ${ }^{51}$ Even the most straightforward eighteenth-century title pages need to be taken with a grain a salt-Anne Dodd never published or sold the Dunciad, despite her name appearing on the title page; ${ }^{52}$ Pope's poem itself was first printed in London, not Dublin, as the imprint claims, ${ }^{53}$ John Gay never wrote The Petticoat (1716), even if the bookseller Edmund Curll hoped less attentive readers might mistake the "J. Gay" that appeared on its title page for the newly famous author of Trivia.$^{54}$ Piracies only exacerbate these problems by closely and silently replicating legally published works by actual copyright holders..$^{55}$

Establishing at least one means of attributing such works would allow us to take the first step in clearing away the brambles of book historyit gives us, sometimes provisionally though often definitively, the name of at least one actor in the life cycle of a text. From this one attribution, especially if made to printers like Henry Woodfall, the Bowyers, James Bettenham, or Thomas Read, who all had long and widespread professional lives in the eighteenth-century London book trade, we would be able to expand our circle of knowledge using anecdotal and additional circumstantial evidence. Printers' ornaments are one way of doing this. From there, we might be able to devise more thorough models for the operation of the illicit book trade in eighteenth-century London. ${ }^{56}$

51. See, for instance, Michael F. Suarez, S. J., review of Barbara M. Benedict, Making the Modern Reader: Cultural Mediation in Early Modern Literary Anthologies (Princeton: Princeton University Press, 1996), in Modern Philology 97, no. 2 (1999): $283-86$.

52. In fact, in an affidavit sworn to Dodd in 1729 , she confirms she had nothing to do with the poem ( $\mathrm{C}_{11} / 2581 / 36$, National Archives).

53. Vander Meulen, Introduction, Pope's Dunciad of 1728, 29-40; and "The Printing of Pope's Dunciad, 1728," Studies in Bibliography 35 (1982): 273ff.

54. Ralph Straus, The Unspeakable Curll (London: Chapman and Hall, 1927), 78.

55. See, for instance, William Zachs, The First John Murray and the Late Eighteenth-Century London Book Trade (Oxford: Oxford University Press, for the British Academy, 1998), 62; or Adrian Johns, Piracy: The Intellectual Property Wars from Gutenberg to Gates (Chicago: University of Chicago Press, 2009), 8.

56. I would like especially to thank John P. Chalmers for affording me access to his ornament catalogues and the staff of the Newberry Library in Chicago for offering me a place to work on this project. 